\title{
Role of Calcium in Glucagon Secretion
}

\author{
Willy J. Malaisse \\ Department of Biochemistry, Université Libre de Bruxelles, Brussels, Belgium \\ Email: malaisse@ulb.ac.be
}

Received 28 January 2014; revised 6 March 2014; accepted 14 March 2014

Copyright (C) 2014 by author and Scientific Research Publishing Inc.

This work is licensed under the Creative Commons Attribution International License (CC BY).

http://creativecommons.org/licenses/by/4.0/

(c) (i) Open Access

\begin{abstract}
The role of calcium ions in the process by which nutrients affect glucagon secretion by pancreatic islet $\alpha$-cells remains the matter of an apparently endless debate. In the prolongation of recent articles dealing with this matter, the present review draws attention to the dual role of $\mathrm{Ca}^{2+}$ as revealed by prior publications. In such a perspective, emphasis is placed on the increase in glucagon output in response to the omission of extracellular $\mathrm{Ca}^{2+}$ as recorded in the presence of D-glucose or 2-ketoisocaproate, the permissive role of extracellular $\mathrm{Ca}^{2+}$ in the positive secretory response to arginine or a mixture of fumarate, glutamate and pyruvate, and the effects of an organic calcium-antagonist on glucagon output. Considering the role currently ascribed to $\mathrm{Ca}^{2+}$ in the activation of motile events involved in stimulus-secretion coupling, attention is also given to the effects of cytochalasin $\mathrm{B}_{1} \mathrm{D}_{2} \mathrm{O}$ and mitotic-spindle inhibitors upon the secretory response of $\alpha$-cells exposed to $D$-glucose in the absence or presence of arginine.
\end{abstract}

\section{Keywords}

Calcium Ions, Glucagon Secretion, Verapamil, Nutrional Factors, Microtubular-Microfilamentous System

\section{Introduction}

The role of calcium ions in the process by which nutrients affect glucagon secretion by pancreatic islet $\alpha$-cells apparently remains the matter of an endless debate. A current view suggests that the inhibition of glucagon release by D-glucose is attributable to the suppression of a depolarising $\mathrm{Ca}^{2+}$ store-operated current [1]. In two articles recently published, consideration was again given to the possible role of changes in calcium handling in the secretory response of glucagon-producing cells to selected secretagogues [2] [3]. These two recent publications both deal mainly with the role of ATP-sensitive potassium channels in the control of glucagon secretion by secretagogues such as D-glucose and tolbutamide. In the present review, attention is drawn to prior publications dealing with the same issue but not cited in the two recent articles. 


\section{Omission of Extracellular $\mathrm{Ca}^{2+}$}

An increase in glucagon output in response to the omission of extracellular $\mathrm{Ca}^{2+}$ was first documented in vitro, using pieces of pancreas from duct-ligated rats incubated in the presence of $8.3 \mathrm{mM}$ D-glucose [4]. Much higher rates of glucagon secretion were even observed in the concomitant absence of $\mathrm{Ca}^{2+}$ and $\mathrm{Mg}^{2+}$ or in calciumdepleted media supplemented with the chelating agent EGTA [4].

The positive secretory response of glucagon-producing cells to a lowering of extracellular $\mathrm{Ca}^{2+}$ concentration from $1.92 \pm 0.21$ to $0.17 \pm 0.01 \mathrm{mM}$ was then documented in the perfused rat pancreas [5]. During the early period of calcium deprivation (min 2 to 7 ), the output of glucagon was higher in experiments conducted throughout in the presence of $3.3 \mathrm{mM}$ as distinct from $8.3 \mathrm{mM}$ D-glucose. During the late period of calcium deprivation (min 8 to 30), however the output of glucagon was positively related to the D-glucose concentration (3.3, 5.5, 8.3 or $16.7 \mathrm{mM}$ ), in mirror image of that observed before the decrease in $\mathrm{Ca}^{2+}$ concentration (initial control period of $15 \mathrm{~min}$ ). At $16.6 \mathrm{mM}$ D-glucose, the sustained stimulation of glucagon release observed over $30 \mathrm{~min}$ of calcium deprivation was rapidly suppressed upon restoration of the control $\mathrm{Ca}^{2+}$ concentration. It was speculated that such a paradoxical stimulation of glucagon release by D-glucose during calcium deprivation may result from a perturbation in the normal structural and functional bridging between distinct types of endocrine pancreatic cells [5].

\section{Dual Role of $\mathrm{Ca}^{2+}$}

The view that calcium may play, at least, a dual role-both inhibitory and permissive-in glucagon secretion was further examined in the rat pancreas perfused throughout the experiment at either $1.86 \pm 0.02 \mathrm{mM}$ or $0.09 \pm$ $0.01 \mathrm{mM} \mathrm{Ca}^{2+}$ concentration and exposed for a period of $30 \mathrm{~min}$ to either a rise in D-glucose concentration from 3.3 to $16.6 \mathrm{mM}$ or, inversely, to a decrease in D-glucose concentration from 16.6 to $3.3 \mathrm{mM}$ [6]. The increase in $\mathrm{D}$-glucose concentration inhibited glucagon release at the high $\mathrm{Ca}^{2}$ level. Likewise, the decrease in D-glucose concentration augmented glucagon output at the high $\mathrm{Ca}^{2+}$ concentration, but failed to do so at the low $\mathrm{Ca}^{2+}$ level [6].

Advantage was then taken of the fact that arginine $(10 \mathrm{mM})$ provokes in the perfused rat pancreas a rapid, sustained and rapidly reversible stimulation of glucagon release, such a biphasic response being inversely related in its magnitude to the environmental D-glucose concentration (3.3 versus $16.6 \mathrm{mM}$ ) [7]. Thus, the versatile role of calcium in glucagon release was further illustrated by the finding that, in the presence of $3.3 \mathrm{mM}$ D-glucose, the positive secretory response of glucagon-producing cells to arginine was virtually abolished when the experiments were conduced throughout at $0.08 \mathrm{mM} \mathrm{Ca}^{2+}$ and the amino acid administred for $30 \mathrm{~min}$ from the $41^{\mathrm{st}}$ to $70^{\text {th }}$ min [8]. At the same low D-glucose concentration, but after only 10 min of calcium deprivation, arginine was still able to provoke a modest early peak-shaped stimulation of glucagon output which, however, was about 8 times lower than that otherwise recorded at $1.97 \pm 0.07 \mathrm{mM} \mathrm{Ca}^{2+}$ concentration [8].

\section{Effects of Verapamil}

In fair agreement with these findings, it was observed that the organic calcium-antagonist verapamil $(10 \mu \mathrm{M})$ administered for 30 min increases glucagon output from the rat pancreas exposed throughout the experiment to $3.3 \mathrm{mM}$ D-glucose, whilst failing to affect the lower glucagon output recorded in the presence of $16.6 \mathrm{mM}$ D-glucose again administered throughout the experiment [9]. The administration of verapamil $(20 \mu \mathrm{M})$ for 30 min, however, severely decreased glucagon output, after a short-lived secretory burst, from the pancreas exposed throughout the experiment to both $3.3 \mathrm{mM}$ D-glucose and $10.0 \mathrm{mM}$ arginine, whilst only causing a minor decrease in the much lower output of glucagon from the pancreas exposed throughout the experiment to both 16.6 mM D-glucose and $10.0 \mathrm{mM}$ arginine [9]. Moreover, when verapamil $(20 \mu \mathrm{M})$ was present throughout the experiment, it severely decreased the early secretory response to arginine $(10.0 \mathrm{mM})$ and, thereafter, revealed an inhibitory action of arginine upon glucagon output, in experiments conducted throughout at $3.3 \mathrm{mM}$ D-glucose. At 16.6 mM D-glucose and in the presence of verapamil throughout the experiment, the administration of arginine $(10 \mathrm{mM})$ for 30 min only caused a short-lived increase in glucagon output as distinct from the biphasic response to arginine otherwise recorded under the same experimental conditions except for the absence of verapamil [9]. Last, in the same series of experiments and when verapamil $(20 \mu \mathrm{M})$ was infused throughout the experiment, the calcium-antagonist did not prevent the inhibition of glucagon release otherwise recorded in 
response to a rise in D-glucose concentration (from 3.3 to $16.6 \mathrm{mM}$ ) and only reduced the late phase of the stimulation of glucagon release otherwise recorded in response to a fall in D-glucose concentration (from 16.6 to $3.3 \mathrm{mM}$ ) as indeed observed in the absence of verapamil [9].

\section{Modulation by Nutritional Factors}

The calcium dependency of glucagon release and its modulation by nutritional factors was then the matter of a further investigation conducted in the perfused rat pancreas [10]. It extended to a mixture of fumarate, glutamate and pyruvate (5.0 $\mathrm{mM}$ each) the rapid, sustained and rapidly reversible inhibition of glucagon release in response to a decrease in $\mathrm{Ca}^{2+}$ concentration from $2.11 \pm 0.05 \mathrm{mM}$ to $0.12 \pm 0.02 \mathrm{mM}$, as otherwise observed in the presence of arginine (10.0 mM) at the same low concentration of D-glucose (3.3 mM). Likewise, at $16.6 \mathrm{mM}$ D-glucose, the decrease in $\mathrm{Ca}^{2+}$ concentration augmented glucagon output whether in experiments conducted throughout in the presence of either the fumarate, glutamate and pyruvate mixture or arginine. When verapamil $(20 \mu \mathrm{M})$ was administered for $30 \mathrm{~min}$, it also decreased glucagon output from the pancreas exposed throughout to $3.3 \mathrm{mM}$ D-glucose and either the fumarate, glutamate and pyruvate mixture or arginine $(10.0 \mathrm{mM})$. At 16.6 $\mathrm{mM}$ D-glucose and in the presence of either the same mixture or arginine, the administration of verapamil only provoked a slight decrease of the much lower rates of glucagon output recorded at the high (16.6 mM) as distinct from low (3.3 mM) D-glucose concentration [10].

There was also a close similarity between the influence of calcium omission upon the secretory response of glucagon-producing cells to either a rise in D-glucose concentration or the administration of 2-ketoisocaproate. Thus, in a first study, it was documented that, at normal $\mathrm{Ca}^{2+}$ concentration, the effects of 2-ketoisocapraote $(10.0 \mathrm{mM})$ administered for $25 \mathrm{~min}$ in the perfused rat pancreas exposed throughout to $3.3 \mathrm{mM}$ D-glucose is comparable to that evoked by a rise in D-glucose concentration from 3.3 to $16.6 \mathrm{mM}$ [11]. In both cases, a rapid and sustained inhibition of glucagon output was recorded, it being only reversed to a limited extent after either the administration of 2-ketoisocaproate or restoration of a low D-glucose concentration. Also in both cases, a biphasic positive secretory response of insulin-producing cells was observed, such a stimulation of insulin output being however more pronounced in response to the administration of 2-ketoisocaproate than in response to the rise in D-glucose concentration. When comparable experiments were conducted in the concomitant presence of $3.3 \mathrm{mM}$ D-glucose and $10.0 \mathrm{mM}$ arginine (present in the perfusate throughout the experiment), a rapid, sustained and only reversed to a limited extent inhibition of glucagon output again occurred in response to either the administration of 2-ketoisocapraote or the rise in D-glucose concentration, this coinciding with biphasic and rapidly reversed increases in insulin output of comparable magnitude in the experiments dealing with the response to either 2-ketoisocaproate or the rise in hexose concentration. As expected, in these experiments, the glucagon and insulin secretory rates recorded during the initial control period ( $\min 25$ to 42 ) were much higher in the presence of arginine than in its absence [11].

A second study was undertaken in order to investigate whether, as in the case of a rise in D-glucose concentration, the inhibition of glucagon release by 2-ketoisocaproate would be relieved in response to a decrease in extracellular calcium concentration from $2.37 \pm 0.22 \mathrm{mM}$ to $0.12 \pm 0.02 \mathrm{mM}$ [12]. In this second study, rat pancreases were perfused throughout the experiments in the presence of either both $3.3 \mathrm{mM}$ D-glucose and 10.0 $\mathrm{mM}$ 2-ketoisocaproate or sole presence of $11.1 \mathrm{mM}$ D-glucose. In the former case, calcium deprivation from the $42^{\text {nd }}$ to $65^{\text {th }}$ min of the experiment provoked a rapid, sustained and rapidly reversible increase in glucagon output, such an increment in glucagon secretory rate being thrice higher when D-glucose (3.3 mM) and 2-ketoisocapraote $(10.0 \mathrm{mM})$ were present throughout the experiment, as distinct from only D-glucose in a higher concentration (11.1 mM). During both the initial equilibration period (min 25 to 43 ) and late perfusion period (min 71 to 87 ), i.e. in the presence of extracellular $\mathrm{Ca}^{2+}$ at a concentration close to $2.3 \mathrm{mM}$, the output of insulin was also much higher in the experiments concerning 2-ketoisocaproate (in the presence of $3.3 \mathrm{mM}$ ) D-glucose than in those experiments conducted in the presence of $11.1 \mathrm{mM}$ D-glucose. In both cases, calcium deprivation caused a rapid, sustained and rapidly reversible inhibition of insulin output. In this second study, it was duly verified that the glucagon released during the period of calcium deprivation displayed the same molecular weight, as judged from gel chromatography, as a suitable glucagon standard [12].

\section{Other Cationic Manipulations}

The omission of extracellular calcium does not represent the sole cationic manipulation that affects in a dual 
manner the release of glucagon. Briefly, and just as an example, when the effects of $\mathrm{K}^{+}$deprivation or ouabain $(0.1,0.5$ and $1.0 \mathrm{mM})$ on glucagon and insulin release from the perfused rat pancreas were studied in the absence or presence of arginine $(10.0 \mathrm{mM}), \mathrm{K}^{+}$deprivation resulted, in the absence of arginine and both at low (2.8 $\mathrm{mM})$ or higher $(8.3 \mathrm{mM})$ concentration of glucose in an inhibition of glucagon release, whereas ouabain enhanced glucagon secretion [13]. In the presence of arginine, $\mathrm{K}^{+}$deprivation induced limited and short-lived oscillations in the rate of glucagon release at both low and high glucose levels. In the presence of arginine, ouabain induced first a short-lived stimulation and, thereafter, a severe and sustained inhibition of glucagon release. The restoration of the normal $\mathrm{K}^{+}$concentration or the removal of ouabain was followed by a marked and transient inhibition of glucagon release, which was most prominent in the presence of arginine. These findings suggested that a primary alteration in $\mathrm{K}^{+}$availability and/or transport affects in a dual manner the release of glucagon, depending on environmental factors such as the type of stimulus used to activate the secretory process [13].

\section{Microtubular-Microfilamentous System}

Considering that the stimulation of insulin release by several secretagogues is currently ascribed to the activation by cytosolic $\mathrm{Ca}^{2+}$ of motile events involved in the intracellular translocation of secretory granules along oriented microtubular pathways and their exocytosis under control of the microfilamentous cell web, attention was paid to the possible role of a microtubular-microfilamentous system in glucagon secretion [14]. This was investigated in pieces of pancreas from duct-ligated rats incubated for 7 to 10 successive periods of 30 min each in the presence of $8.3 \mathrm{mM}$ D-glucose.

The effect of a microfilamentous-modifier, i.e. cytochalasin B $(10 \mu \mathrm{g} / \mathrm{ml})$ was first examined. As expected, cytochalasin B enhanced insulin secretion evoked by $8.3 \mathrm{mM}$ D-glucose, such an effect being reversed after removal of a mould metabolite. Cytochalasin B, however, did not affect the inhibited release of glucagon seen in the presence of $8.3 \mathrm{mM}$ D-glucose. In the control experiments (no cytochalasin B), arginine $(10.0 \mathrm{mM})$ increased both insulin and glucagon output from the pieces of pancreas exposed throughout the experiment to 8.3 $\mathrm{mM}$ D-glucose. In these control experiments, the secretory effects of arginine rapidly faded out after removal of the amino acid from the incubation medium. Cytochalasin B, when administered together with arginine during the $4^{\text {th }}$ and $5^{\text {th }}$ incubation periods, augmented significantly both the insulinotropic and glucagonotropic actions of arginine. The enhancing action of cytochalasin B upon insulin and glucagon output was rapidly reversed, at least in part, after removal of both arginine and the mould metabolite from the incubation medium. In considering the apparent failure of cytochalasin B to augment glucagon output from pieces of pancreas exposed to $8.3 \mathrm{mM}$ Dglucose, the two following considerations should be underlined. First, assuming that cytochaasin B augmented not only insulin release but also somatostatin release, a paracrine inhibitory effect of the latter hormone upon glucagon output might conceivably have masked the enhancing action of the mould metabolite upon glucagon release, as observed in the concomitant presence of $8.3 \mathrm{mM}$ D-glucose and $10.0 \mathrm{mM}$ arginine and as currently ascribed to the biophysical effect of cytochalasin B upon the microfilamentous cell web. Second, cytochalasin B $(21 \mu \mathrm{M})$ was found to inhibit much more severely D-[5- $\left.{ }^{3} \mathrm{H}\right]$ glucose utilization, as well as D-[U- $\left.{ }^{14} \mathrm{C}\right]$ glucose conversion to ${ }^{14} \mathrm{CO}_{2}$ and radioactive acidic metabolites and amino acids, in non-B rat pancreatic islet cells than in purified islet B-cells [15]. Since such an inhibition could be expected to provoke an increase in glucagon output, the postulated paracrine effect of somatostatin should indeed not be ignored.

The effect of the microtubule-stabilizes $\mathrm{D}_{2} \mathrm{O}$ was then investigated. The pieces of pancreas were incubated for 8 successive periods of 30 mineach in the presence of both D-glucose $(8.3 \mathrm{mM})$ and arginine $(10.0 \mathrm{mM})$, all $\mathrm{H}_{2} \mathrm{O}$ being replaced by $\mathrm{D}_{2} \mathrm{O}$ during periods 4 to 6 . Under these experimental conditions, $\mathrm{D}_{2} \mathrm{O}$ markedly inhibited both glucagon and insulin output, the inhibitory effect of $\mathrm{D}_{2} \mathrm{O}$ being rapidly reversible in both cases. Such findings were consistent with the fact that the stabilizing action of $\mathrm{D}_{2} \mathrm{O}$ results in an impairment of both the intracellular translocation of secretory granules along the microtubular pathway and the exocytosis of those granules already located in close vicinity to the cell web.

Last, the effects of the mitotic-spindle inhibitors colchicine and vinblastine ( $0.1 \mathrm{mM}$ each) were also examined. In pieces of pancreas incubated for 10 successive periods of 30 min each in the sole presence of Dglucose $(8.3 \mathrm{mM})$, no significant effect of colchicine $(0.1 \mathrm{mM})$ upon glucagon output was observed, whether the mitotic-spindle inhibitor was present in the incubation medium only during periods 4 and 5 or from period 4 to period 10. However, in pieces of pancreas first exposed for $120 \mathrm{~min}$ to vinblastine or for $150 \mathrm{~min}$ to colchicine, the increment in glucagon output evoked by the administration of arginine $(10.0 \mathrm{mM})$ was considerably 
higher than that otherwise recorded in control experiments conducted in the absence of any mitotic-spindle inhibitor. This coincided with the expected inhibition of the insulin secretory response to arginine in the pieces of pancreas exposed prior to and during administration of arginine to a mitotic-spindle inhibitor. It was speculated, in the light of the latter findings, that the microtubular apparatus, which in the B-cell is thought to control the oriented intracellular translocation of secretory granules, normally restrains the access of glucagon secretory granules to sites of exocytosis in the A-cells. Alternatively, based on the assumption that mitotic-spindle inhibitors would affect insulin and somatostatin secretion in a comparable manner, it could be proposed that the facilitation of arginine-stimulated glucagon output by colchicine or vinblastine is attributable, in part at least, through a paracrine process, to the concomitant inhibition of somatostatin output [14].

\section{Pattern of Cellular Calcium Localization}

Interestingly, when considering the role of $\mathrm{Ca}^{2+}$ in the secretion of pancreatic hormones, it should be kept in mind that the pattern of calcium localization in islet cells, as studied by the pyroantimanite precipitation technique, differs in distinct endocrine cells [16]. In B-cells, numerous secretory granules contain deposits located in the halo surrounding the granule case. Incidentally, in islets incubated at a high D-glucose concentration or in the presence of the calcium ionophore A23187, the percentage of beta granules containing precipitates is significantly increased, whereas only few deposits are observed in B-cells incubated in a calcium-deprived medium enriched with EGTA. In A-cells, only few granules contain precipitation in their halo, whereas in D-cells, deposits are situated in the dense core of the secretory granules. Moreover, deposits along the plasma membrane occur generally at the outer leaflet of the plasma membrane of B- and D-cells, whilst they are found on the inner leaflet of the plasma membrane in A-cells [16].

\section{Conclusion}

In conclusion, the present commentary emphasizes the view that changes in $\mathrm{Ca}^{2+}$ handling by endocrine islet cells may affect at least in a dual manner the secretion of glucagon. In certain respects, the present article also complements a recent review dealing with the proposed paracrine role of somatostatin in glucagon release [17], as proposed in two recent publications [2] [18].

\section{References}

[1] Vireira, E., Salehi, A. and Gylfe, E. (2007) Glucose Inhibits Glucagon Secretion by a Direct Effect on Mouse Pancreatic Alpha Cells. Diabetologia, 50, 370-379. http://dx.doi.org/10.1007/s00125-006-0511-1

[2] Cheng-Xue, R., Gómez-Ruiz, A., Antoine, N., Noël, L.A., Chae, H.-Y., Ravier, M.A., Chimienti, F., Schuit, F.C. and Gilon, P. (2013) Tolbutamide Controls Glucagon Release from Mouse Islets Differently than Glucose. Involvement of $\mathrm{K}_{\mathrm{ATP}}$ Channels from Both $\alpha$-Cells and $\delta$-Cells. Diabetes, 62, 1612-1622. http://dx.doi.org/10.2337/db12-0347

[3] Gylfe, E. (2013) Glucose Control of Glucagon Secretion: There Is More to It than $\mathrm{K}_{\mathrm{ATP}}$ Channels. Diabetes, 62, 13911393. http://dx.doi.org/10.2337/db13-0193

[4] Leclercq-Meyer, V., Marchand, J. and Malaisse, W.J. (1973) The Effect of Calcium and Magnesium on Glucagon Secretion. Endocrinology, 93, 1360-1370. http://dx.doi.org/10.1210/endo-93-6-1360

[5] Leclercq-Meyer, V., Rebolledo, O., Marchand, J. and Malaisse, W.J. (1975) Glucagon Release: Paradoxical Stimulation by Glucose during Calcium Deprivation. Science, 189, 897-899. http://dx.doi.org/10.1126/science.1098149

[6] Leclercq-Meyer, V., Marchand, J. and Malaisse, W.J. (1976) The Role of Calcium in Glucagon Release. Interactions between Glucose and Calcium. Diabetologia, 12, 531-538. http://dx.doi.org/10.1007/BF01219520

[7] Leclercq-Meyer, V., Marchand, J. and Malaisse, W.J. (1977) An Arginine-Like Effect of the "Fumarate + Glutamate + Pyruvate” Mixture on Glucagon Release. Life Sciences, 20, 1193-1198. http://dx.doi.org/10.1016/0024-3205(77)90492-1

[8] Leclercq-Meyer, V., Marchand, J. and Malaisse, W.J. (1976) The Role of Calcium in Glucagon Release. Interactions between Arginine and Calcium. Hormone Research, 7, 348-362. http://dx.doi.org/10.1159/000178749

[9] Leclercq-Meyer, V., Marchand, J. and Malaisse, W.J. (1978) The Role of Calcium in Glucagon Release. Studies with Verapamil. Diabetes, 27, 996-1004. http://dx.doi.org/10.2337/diab.27.10.996

[10] Leclercq-Meyer, V., Marchand, J. and Malaisse, W.J. (1979) Calcium Dependency of Glucagon Release: Its Modulation by Nutritional Factors. American Journal of Physiology, 236, E98-E104. 
[11] Leclercq-Meyer, V., Marchand, J., Leclercq, R. and Malaisse, W.J. (1979) Interactions of $\alpha$-Ketoisocaproate, Glucose and Arginine in the Secretion of Glucagon and Insulin from the Perfused Rat Pancreas. Diabetologia, 17, 121-126. http://dx.doi.org/10.1007/BF01222213

[12] Leclercq-Meyer, V., Marchand, J., Leclercq, R. and Malaisse, W.J. (1981) Calcium Deprivation Enhances Glucagon Release in the Presence of 2-Ketoisocaproate. Endocrinology, 108, 2093-2097. http://dx.doi.org/10.1210/endo-108-6-2093

[13] Leclercq-Meyer, V., Marchand, J. and Malaisse, W.J. (1983) Effect of $\mathrm{K}^{+}$Deprivation and Ouabain upon Glucagon Release. Endocrinology, 113, 178-183. http://dx.doi.org/10.1210/endo-113-1-178

[14] Leclercq-Meyer, V., Marchand, J. and Malaisse, W.J. (1974) Possible Role of a Microtubular-Microfilamentous System in Glucagon Secretion. Diabetologia, 10, 215-224. http://dx.doi.org/10.1007/BF00423038

[15] Jijakli, H., Zhang, H.-X., Dura, E., Ramirez, R., Sener, A. and Malaisse, W.J. (2002) Effects of Cytochalasin B and D upon Insulin Release and Pancreatic Islet Cell Metabolism. International Journal of Molecular Medicine, 9, 165-172.

[16] Ravazzola, M., Malaisse-Lagae, F., Amherdt, M., Perrelet, A., Malaisse, W.J. and Orci, L. (1976) Patterns of Calcium Localization in Pancreatic Endocrine Cells. Journal of Cell Science, 27, 107-117.

[17] Malaisse, W.J. (2014) Paracrine Control of Glucagon Release by Somatostatin. International Journal of Molecular Medicine, 33, 491-498.

[18] Karimian, N., Qin, T., Liang, T., Osundiji, M., Huang, Y., Teich, T., Riddell, M.C., Cattral, M.S., Coy, D.H., Vranic, M. and Gaisano, H.Y. (2013) Somatostatin Receptor Type 2 Antagonism Improves Glucagon Counterregulation in Biobreeding Diabetic Rats. Diabetes, 62, 2968-2977. http://dx.doi.org/10.2337/db13-0164 